\title{
Longitudinal associations between the use of sexually explicit material and adolescents' attitudes and behaviors: A narrative review of studies
}

\author{
Koletić, Goran
}

Source / Izvornik: Journal of Adolescence, 2017, 57, 119 - 133

Journal article, Accepted version

Rad u časopisu, Završna verzija rukopisa prihvaćena za objavljivanje (postprint)

https://doi.org/10.1016/j.adolescence.2017.04.006

Permanent link / Trajna poveznica: https://urn.nsk.hr/urn:nbn:hr:131:209021

Rights / Prava: Attribution-NonCommercial-NoDerivatives 4.0 International/ImenovanjeNekomercijalno-Bez prerada 4.0 međunarodna

Download date / Datum preuzimanja: 2023-04-26

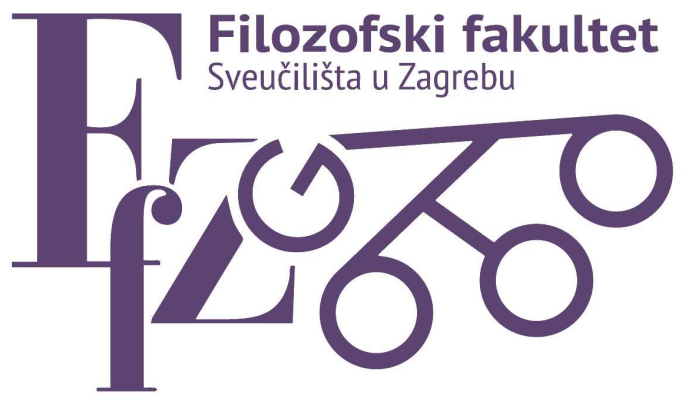

Repository / Repozitorij:

ODRAZ - open repository of the University of Zagreb

Faculty of Humanities and Social Sciences
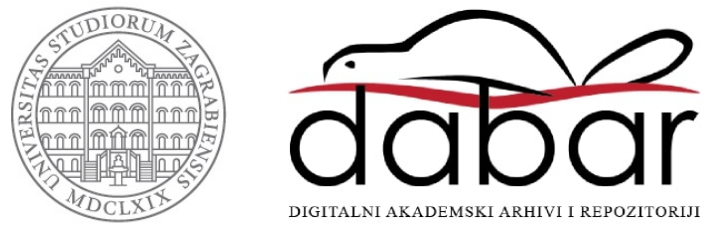


\title{
Longitudinal Associations between the Use of Sexually Explicit Material and
}

\section{Adolescents' Attitudes and Behaviors: A Narrative Review of Studies *}

\author{
Goran Koletić ${ }^{1}$
}

${ }^{1}$ Department of Sociology, Faculty of Humanities and Social Sciences, University of Zagreb, Zagreb, Croatia

\section{Correspondence to:}

Goran Koletić,

Department of Sociology, Faculty of Humanities and Social Sciences University of Zagreb,

Zagreb, Croatia

Ivana Lučića 3, 10000 Zagreb, Croatia

Phone/fax: +38514092042

E-mail: gkoletic@ffzg.hr

\section{Acknowledgement:}

This work has been fully supported by Croatian Science foundation under the project 9221 .

\footnotetext{
* Please cite this article as: Koletić, G. (2017). Longitudinal associations between the use of sexually explicit material and adolescents' attitudes and behaviors: A narrative review of studies. Journal of Adolescence, 57 , 119-133. https://doi.org/10.1016/j.adolescence.2017.04.006

This manuscript version is made available under the CC-BY-NC-ND 4.0 license http://creativecommons.org/licenses/by-nc-nd/4.0/.
} 


\title{
Longitudinal Associations between the Use of Sexually Explicit Material and
} Adolescents' Attitudes and Behaviors: A Narrative Review of Studies

\begin{abstract}
:
This review analyzed longitudinal studies examining the effects of sexually explicit material (SEM) use on adolescents' attitudes, beliefs and behaviors. The review also aimed to provide an analysis of the strengths and limitations of the existing studies, as well as recommendations for future research. A systematic literature search was performed using Medline, PubMed, PsycINFO, ScienceDirect and Web of Science. To be included, publications had to employ repeated measurements (at least two data collection points), include a measure of SEM use or exposure and participants aged 18 years or less. A total of 20 papers from nine different research projects were included in the review. The database search was conducted in September 2015. The selected studies were mainly focused on the possible negative effects of the SEM use. The results show that SEM use or exposure is associated with sexual behavior, sexual norms and attitudes, gender attitudes, self-esteem, sexual satisfaction, uncertainty and preoccupancy. In addition, the studies reported developmental effects of SEM on adolescents' behavioral, cognitive and emotional wellbeing. A number of gaps were identified in the literature, including a lack of replication efforts. Because experimental studies on SEM use among young people are not feasible, more methodologically rigorous longitudinal studies - followed by a meta-analysis — are needed to further our understanding of the effects of SEM in this population.
\end{abstract}

Key Words: sexually explicit material; adolescence; longitudinal studies; review 


\section{INTRODUCTION}

Technological advancements such as smartphones and tablet computers have enabled fast and easy access to Internet-based sexually explicit material (SEM). Using the concept of the Triple-A engine (anonymity, affordability and accessibility), Cooper (1998) pointed to the characteristics that distinguish Internet SEM from earlier forms. The contemporary omnipresence of SEM has been related to an increase in the diversity of its content. More than four million pornographic websites contain SEM of unprecedented quantity and diversity (Ropelato, 2007).

Given that a great majority of adolescents in Western countries have access to the Internet, exposure to and use of SEM is no longer restricted to adults (Owens, Behun, Manning, \& Reid, 2012). Empirical evidence suggests that a substantial proportion of adolescents use SEM (Peter \& Valkenburg, 2006a, 2011c; Wolak, Mitchell, \& Finkelhor, 2007). According to a large probability-based study carried out in the US, 93\% of male and $62 \%$ of female adolescents were exposed to SEM before the age of 18 (Sabina, Wolak, \& Finkelhor, 2008).

The findings that exposure to pornography precedes first sexual experiences (Brown \& L'Engle, 2009) point to a potentially socializing role of SEM (Stulhofer, Busko, \& Landripet, 2010; Wright, 2012). This led to a growing concern among policy makers and the general public regarding online SEM use among young people and its presumed (negative) effects on adolescents' attitudes, beliefs and behaviors. In 2013, David Cameron's government enforced online traffic restrictions in the UK by making a variety of web sites, including pornographic sites, available by request only ("Online pornography to be blocked by default, PM announces,” 2013; Petley, 2014). This legislation was preceded by the Office of the Children's Commissioner's report on the commercialization and sexualization of childhood (Horvath et al., 2013), which emphasized the harmful effects of sexualized media on children 
and parents' concerns related to the efficient protection of their children's well-being. In the report's conclusion, the authors stated that children and young people's exposure to pornography has been associated with risky sexual behavior and that pornography affects their sexual beliefs (e.g., having unrealistic expectations about sex or having greater acceptance of casual sex). In 2013, the European Parliament debated a proposal to ban pornography to protect children and adolescents from degrading and violent sexual imagery ("Will porn be banned in Europe? EU set to vote on internet crackdown.," 2013). At the same time, a similar proposal was put forward by Iceland's government ("Iceland seeks internet pornography ban,” 2013). Both proposals were later rejected (Whittaker, 2013).

Coinciding with rising public concerns is an increasing interest in the scientific study of SEM use among young people (Hald, Kuyper, Adam, \& de Wit, 2013; Löfgren-Mårtenson \& Månsson, 2010; Luder et al., 2011; Mattebo, Tydén, Häggström-Nordin, Nilsson, \& Larsson, 2013; Svedin, Åkerman, \& Priebe, 2011; Ševčíková \& Daneback, 2014; Weber, Quiring, \& Daschmann, 2012). Focusing primarily on the possible negative effects of intentional or accidental SEM exposure, social scientists have been exploring interpretations of SEM and the adoption of SEM-related attitudes, expectations and behaviors among adolescents (Braun-Courville \& Rojas, 2009), as well as the developmental co-occurrence of SEM use and sexual behaviors and their cognitive, emotional, health-related and social implications. For example, researchers have been assessing the impact of SEM on adolescents' sexually aggressive behavior (Alexy, Burgess, \& Prentky, 2009; Brown \& L’Engle, 2009; Malamuth \& Huppin, 2005; Ybarra, Mitchell, Hamburger, Diener-West, \& Leaf, 2011), risky sexual behavior (Brown, Keller, \& Stern, 2008; Collins, Martino, \& Shaw, 2011; Peter \& Valkenburg, 2011; Wingood et al., 2001), sexual uncertainty (Peter \& Valkenburg, 2008b, 2010a; van Oosten, 2015) and attitudes toward women as sex objects (Peter \& Valkenburg, 2007, 2009). 
The literature on adolescents' online SEM use was recently summarized by Owens et al. (2012) and Peter and Valkenburg (2016). Both reviews included qualitative and quantitative studies. An overwhelming majority of the selected studies were cross-sectional, making causal inferences impossible. For example, the directionality of a significant association between SEM use and recreational attitudes toward sex reported by Peter and Valkenburg (2006) remains unknown and cannot be ascertained using a cross-sectional design. This is a serious limitation, particularly when considering the great demand for evidence-based policy making. However, experimental studies, which are considered to be the “golden standard” for exploring causal relationships (Shadish, Cook, \& Campbell, 2002), would clearly be unethical in this context (Peter \& Valkenburg, 2014). Furthermore, finding a control group with no exposure to SEM seems increasingly less possible.

In the absence of experimental studies, researchers interested in exploring causal links resort to a longitudinal research design (Shadish, Cook, \& Campbell, 2002). In addition to their clear advantages (prospective character) over studies using a cross-sectional design, longitudinal studies enable insights into the developmental dynamics and time-related characteristics (Lynn, 2014) of young people's SEM use. Taking logistic, methodological, financial and ethical (Caskey \& Rosenthal, 2005) complexities of longitudinal research into consideration, the small number of longitudinal studies available on adolescents' SEM use is not surprising.

Despite the abovementioned difficulties, longitudinal studies are needed for a better and more rigorous understanding of the possible effects of SEM use on adolescents' sexual and reproductive health and well-being. The same is true for policy planning and decision making aimed at protecting young people from detrimental media influences. 
Currently, four reviews of Internet SEM use and its correlates are available (Döring, 2009; Owens et al., 2012; Peter \& Valkenburg, 2016; Short, Black, Smith, Wetterneck, \& Wells, 2012) with two focusing on adolescents (Owens et al., 2012; Peter \& Valkenburg, 2016). Although these reviews included some of the available longitudinal studies, this is the first review exclusively focused on longitudinal panel studies of adolescent SEM use, their methodological characteristics and key findings. This focus enables a more comprehensive insight into potential effects of SEM use among adolescents. It also contributes to the identification of gaps and shortcomings in the current understanding of this topic and provides recommendation for future research by analyzing conceptual and methodological limitations of the relevant studies.

\section{METHOD}

\section{Search Strategy}

The following electronic databases were searched for relevant publications: Medline, PubMed, PsycINFO, ScienceDirect and Web of Science. The keywords for SEM exposure/use were "porn," "pornography," "online pornography," "cyber pornography," "Internet erotica," "sexually explicit media" and "sexually explicit material." The keywords for the target population were "adolescent," "minor," "teenager," "juvenile" and "youth." Various combinations of these keywords were used in the database search. Additional manual searches included titles of interest listed in the selected publications' lists of references. If a publication of interest was not available in full text, its authors were contacted and asked to provide a copy. The database search was conducted in September 2015.

Inclusion was based on five criteria: (a) measure of interest, (b) participants' age, (c) study design, (d) publication type and (e) language. To be eligible for the analysis, publications had to employ repeated measurements (i.e., include at least two data collection points), include a measure of SEM use or exposure and report on participants aged 18 years or 
less. Only articles written in English and published in peer-reviewed journals or books were included. Studies on other online sexual activities (e.g., sexual information seeking, sexting ${ }^{\dagger}$ or online dating using chat rooms, bulletin boards or peer-to-peer networks) were excluded from this review.

Figure 1 depicts the search process. After removing duplicates from an initial 744 articles, the remaining 446 articles were screened on the basis of their title and abstracts to determine which full-text articles would be assessed for eligibility. After examining 61 fulltext articles, 20 were retained for the review. The reference lists of these articles were screened for additional articles that might have been missed in the database search.

\section{FIGURE 1 ABOUT HERE}

\section{RESULTS}

A total of 20 papers met the criteria for inclusion. The papers were linked to nine different research projects carried out in three countries (the Netherlands, the US, and Belgium). The earliest research project was conducted in 2001 and the most recent one in 2013. Five projects had a three-wave design, three had a two-wave design and one had a fourwave design. Other details of the research projects are summarized in Table 1. With regard to the outcomes of SEM use, nine studies examined attitudes or beliefs, six examined patterns of SEM use, four examined sexual behaviors, two examined sexual aggression and one assessed a non-sexual behavior. Participants' age ranged between 10 and 20 years, with the exception of one research project that also included adults. The number of participants ranged from 325 to 1765 . Other details of the reviewed papers are summarized in Table 2.

Patterns of SEM Use and Exposure to SEM

\footnotetext{
${ }^{\dagger}$ An activity that includes sending a nude picture or being asked for a nude picture (Klettke, Hallford, \& Mellor, 2014).
} 
Developmental trajectories of SEM use and sexual behavior were the focus of the study conducted by Doornwaard, van den Eijnden, Overbeek and Ter Bogt (2014). Their analyses pointed to several different trajectory profiles in male and female adolescents. The former were characterized by four distinguishable SEM use profiles (no or infrequent use, increasing use, occasional use and decreasing use), while the latter had three (no or infrequent use, increasing use and occasional use). In comparison to $22 \%$ of male adolescents, only $5 \%$ of female adolescents were characterized by increasing SEM use (about $92 \%$ of them reported no or infrequent use). All seven SEM use profiles had different initial levels of sexual experience and increasing sexual behavior over time. The highest increase of sexual behavior over time was reported by male adolescents with a decreasing SEM use profile and female adolescents with an increasing SEM use profile. A multivariate analysis of the predictors of SEM trajectories among male adolescents pointed to significant effects of age, permissive attitudes, initial sexual interest, perceived realism of SEM, communication with parents, disclosure to parents about their whereabouts and personal Internet access. Among female adolescents, only initial sexual interest and perceived SEM realism were significant predictors of SEM use.

The same research team also examined whether depression, self-esteem, excessive sexual interest, impulsiveness and callous/unemotional and grandiose/manipulative psychopathic traits predict the symptoms of compulsive SEM use in male adolescents (Doornwaard, van den Eijnden, Baams, Vanwesenbeeck, \& ter Bogt, 2015). Compulsive SEM use was indicated by a lack of control over one's use, preoccupation with use, frustration when use is impossible, adverse consequences of use and SEM use as a way of coping with negative feelings. Based on this operationalization, $11 \%$ of the participants were categorized as compulsive SEM users. According to the findings, depression and excessive sexual interest at baseline were risk factors for compulsive SEM use six months later. 
In a two-wave study on Dutch adolescents, Vandenbosch (2015) examined use and exposure to three content-specific types of SEM, the antecedents of this exposure and likely gender differences. SEM content was divided in affection-themed, dominance-themed and violence-themed categories (Klaassen \& Peter, 2015). Affection-themed SEM was defined as depicting non-degrading and affectionate sexual activity in an intimate context. In contrast, violence-themed SEM included aggression, physical pain or harm being inflicted on the sexual partner(s). Dominance-themed SEM was defined as showing a dominant male or female character who is imposing his/her power or wishes on his/her sexual partners or the individuals included in the sexual activities. Age, academic achievement, religiosity, sensation seeking and hypergendered orientation were explored as antecedents of the exposure to the different SEM categories. Hypergendered orientation was indicated by hypermasculinity—as the endorsement of male dominance and hostility—and hyperfemininity — as the endorsement of female submission, objectification and importance of physical attractiveness (Kreiger \& Dumka, 2006; Murnen \& Byrne, 1991). Participants most frequently used dominance-themed SEM and least frequently used violence-themed SEM. Younger adolescents used affection-themed SEM more frequently than their older peers. Older adolescents and those with higher academic achievement used dominance-themed SEM more often than others. Finally, exposure to violence-themed SEM was predicted by higher levels of hypermasculinity among male and hyperfemininity among female adolescents.

To address the question about potential differences in SEM use and its effects in adolescence and adulthood, Peter and Valkenburg (2011b) conducted a two-wave longitudinal study among 1445 adolescent and 833 adults. No significant differences were found between the two groups in the frequency of SEM use. Both male adolescents and adults consumed SEM more frequently than female participants. Higher sensation seeking, lower life satisfaction and not being exclusively heterosexual significantly increased SEM use, 
regardless of gender. Using the same data, Peter and Valkenburg also examined whether SEM affected sexual risk taking (2011a) and stereotypical beliefs about women's sexual roles (2011). Both hypotheses were corroborated only in the adult sample.

\section{TABLE 1 ABOUT HERE}

\section{Attitudes and Beliefs}

Sexual beliefs, values, worries and explorations are part of adolescents' developing sense of sexual identity (Breakwell \& Millward, 1997). Defining sexual uncertainty as a degree of unclarity about sexual beliefs and values, Peter and Valkenburg (2010a) addressed sexual uncertainty in relation to SEM use. Their results showed that frequent SEM exposure significantly increased sexual uncertainty among adolescents. The authors also explored a mediating role of involvement, which was defined as an intense state of being both affectively and cognitively engaged by a particular media content (Peter \& Valkenburg, 2010a). The analysis confirmed that involvement in SEM mediated the effect of SEM use on sexual uncertainty. Gender differences were significant only for the effect of SEM use on involvement, which was stronger among female adolescents.

In another longitudinal study carried out on more than 1700 Dutch adolescents, van Oosten (2015) assessed sexual disposition as a moderator of the effect of SEM on sexual uncertainty. The author analyzed within-gender differences in impersonal sex orientation and hypergendered orientation. Impersonal sex orientation refers to the degree of accepting sex without emotions and commitment (Malamuth, Addison, \& Koss, 2000). The findings revealed that only female adolescents high in impersonal sex orientation and those scoring low in hypergendered orientation were susceptible to sexual uncertainty following SEM use.

In their examination of SEM use and sex-related cognitions, Peter and Valkenburg (2008a) found a positive relationship between SEM use and sexual preoccupancy, a concept defined as strong cognitive engagement in sexual issues (sometimes at the exclusion of other 
thoughts). After including subjective sexual arousal in the model, the direct link between SEM use and preoccupancy disappeared, pointing to full mediation of the initial relationship. This indirect effect was shown to be gender non-specific.

In the same three-wave panel study, Peter and Valkenburg (2009) also investigated the relationship between SEM use and sexual satisfaction, with gender and the indicators of sexual experience and perceived peer norms as potential moderators. The analysis pointed to a bi-directional influence between SEM use and sexual satisfaction - that is, more frequent SEM use reduced sexual satisfaction and vice versa. Sexual experience moderated this relationship. Compared to other participants, the effect of SEM use on sexual satisfaction was smaller among more experienced adolescents. A reduced effect of SEM use was also found among adolescents who perceived their peers to be sexually experienced. There were no differences between male and female adolescents.

Possible causal pathways between SEM use and adolescents' notions of women as sex objects were explored in another research paper by Peter and Valkenburg. The authors defined sexual objectification as "ideas about women that reduce them to their sexual appeal" (Peter \& Valkenburg, 2009a, p. 408). The analyses showed a positive bi-directional relationship between SEM use and female sexual objectification. With increased exposure to SEM, both male and female adolescents tended to see women as sex objects, but the process of objectification had a positive effect on SEM use only among male adolescents. Authors also included liking of SEM — an affective response to media content—as a potential mediator of the relationship between SEM use and sexual objectification. Both the influence of SEM use on the objectification of women and the influence of objectification on SEM use were partially mediated by participants' liking of SEM.

Perceived realism has been assessed as a potential mediator of the relationship between SEM use and instrumental attitudes toward sex, that is, recreational sex attitudes 
(Peter \& Valkenburg, 2010b). In the study, perceived realism consisted of two dimensions: social realism, which entailed the similarity between SEM content and sex in real life, and social utility, which tapped into the usefulness of SEM as a source of information about reallife sex. Using longitudinal data, the authors found that SEM use increased recreational sex attitudes among adolescents. As hypothesized, perceived realism mediated the association in a way that SEM use increased social realism and utility, which in turn increased the acceptance of recreational sex attitudes.

In a paper from another three-wave Dutch study, Baams et al. (2014) reported that perceived realism moderated the association between adolescents' consumption of sexualized media (SEM included) and permissive sexual attitudes. The study found that increased sexualized media use was associated with increased sexual permissiveness at both the initial measurement point and over time. Interestingly, higher initial levels of sexualized media use resulted in a slower development of permissive attitudes among male adolescents. After including perceived sexualized media realism (low vs. relatively high) in the multi-group analysis, the association between initial levels of sexualized media consumption and sexual permissiveness remained positive. The association between increases in sexualized media use and sexual permissiveness was positive only among participants characterized by high perceived realism.

Permissive sexual norms were assessed in the first longitudinal study on SEM use among adolescents in the US. In a sample of almost 1,000 young people, Brown and L'Engle (2009) showed that male adolescents exposed to SEM at an earlier age were more likely to internalize permissive sexual norms. These results are in line with the findings from a several cross-sectional studies (Braun-Courville \& Rojas, 2009; Peter \& Valkenburg, 2006). Early exposure to SEM also predicted less progressive gender role attitudes, but only among female adolescents. 
One of the emerging topics in recent research has been the influence of SEM use on adolescents' body image (Häggström-Nordin, Sandberg, Hanson, \& Tydén, 2006; LöfgrenMårtenson \& Månsson, 2010). In a recent four-wave longitudinal study, Doornwaard, Bickham, et al. (2014) addressed the problem of Dutch adolescents' body image and sexual self-perception as a consequence of sex-related online behavior (SEM use, sexual information seeking, cybersex and online social networking). Using latent growth curve modeling, the authors found that male adolescents reported higher initial levels of SEM use and a steeper increase in SEM use compared to their female peers. Male adolescents with higher initial SEM use also reported higher body surveillance and lower sexual satisfaction. A steeper increase in SEM use over time resulted in lower sexual satisfaction levels among female adolescents.

\section{Sexual Behavior}

The first longitudinal study to examine the relationship between SEM use and sexual behavior was a study by Brown and L'Engle (2009). The authors found that SEM exposure in early adolescence increased the likelihood of engaging in oral sex and sexual intercourse, and the effect was somewhat stronger for male adolescents. Similar results were found by a Belgium team examining the relationship between SEM use and sexual initiation (Vandenbosch \& Eggermont, 2013). The results from their two-wave study on 639 adolescents showed that frequent SEM use increased the likelihood of having sexual intercourse. Another noteworthy result from this study was that pubertal status was shown to moderate this finding. Adolescents in early pubertal stages at baseline were more likely to initiate sexual intercourse after using SEM than their peers in more advanced pubertal stages.

Hennessy, Bleakley, Fishbein and Jordan (2010) confirmed a bi-directional association between SEM exposure and sexual experience with the results from their three-wave study on a national sample of adolescents in the US. Additional analyses showed that adolescents with 
higher initial levels of sexual experience were characterized by decreasing SEM exposure. Racial and ethnic differences were also observed: Both Caucasian and Hispanic/AfricanAmerican participants who reported higher initial levels of sexual experience reported higher SEM use at baseline. However, the association between initial levels of sexual experience and the dynamics of exposure to SEM was significant only for Caucasian adolescents.

Another study by Doornwaard, ter Bogt, Reitz and van den Eijnden (2015) examined the mediating role of perceived peer norms in the association between SEM use and experience with sexual behavior. The measurement of perceived peer norms included two types of perceived norms: adolescents' perceptions that peers were engaging in sexual behavior (descriptive norms) and the perception that peers approved of sexual behavior (injunctive norms). The analysis of the direct effects revealed that increased SEM use had a positive effect on both types of peer norms but only among male adolescents. In addition, sexual behavior was positively predicted by the increased perception of descriptive norms in both male and female adolescents, but the influence of the perception of injunctive norms was significant only for female adolescents. The analyses did not confirm either the direct effects of SEM use or the indirect effects of perceived peer norms on adolescent experiences with sexual behavior.

Sexual Aggression

This important topic, particularly in the context of the history of research on the effects of pornography use (Hald, Seaman, \& Linz, 2014), has received relatively little attention in longitudinal research among adolescents, despite the indications that SEM use may be a (conditional) risk factor for sexual aggression (Malamuth \& Huppin, 2005; Ybarra \& Mitchell, 2005). Brown and L'Engle (2009) reported that male adolescents were more likely to report sexual harassment perpetration - measured as verbal or physical forms of aggression directed toward someone, including calling names, grabbing and touching —if exposed to 
SEM in early adolescence. In another longitudinal study also carried out in the US, Ybarra and her coauthors (2011) found that adolescents exposed to SEM had significantly higher odds of behaving in a sexually aggressive manner (defined as unwanted kissing/touching, explicit picture and text messaging and sexual information solicitation) than their peers who did not report exposure to SEM, but only if violent SEM was used. Violent sexual material was operationalized in the study as showing a person appearing to be hurt, suffering or in pain during sexual activity. A small minority (5\%) of adolescents reported sexually aggressive behavior.

\section{Non-Sexual Outcomes}

In another report, sensation seeking and pubertal status were significant predictors of online SEM use among male adolescents in Belgium, which, in turn, predicted lower academic performance (Beyens, Vandenbosch, \& Eggermont, 2015). According to the findings, adolescents who were in an advanced pubertal stage used SEM more frequently than did their peers. Sensation seeking marginally but significantly mediated the effects of pubertal status on SEM use.

\section{TABLE 2 ABOUT HERE}

\section{DISCUSSION}

The aim of this study was to provide a narrative review of the longitudinal studies focusing on the effects of SEM use on adolescents. The database search identified 20 eligible studies linked to nine longitudinal research projects. A number of directed associations between SEM use and adolescents' attitudes, beliefs or behaviors were reported in the studies. In this section, we briefly discuss the key findings, assess the studies' limitations and offer some recommendations for future research.

Patterns of SEM Use and Exposure to SEM 
The reviewed studies' findings showed that adolescent SEM use is far from uniform. As they progressively develop their sexual self-i.e., perceive, reflect on and evaluate their own sexual thoughts, feelings and actions (Breakwell \& Millward, 1997; Winter, 1988)— adolescents are characterized by different trajectories of SEM use, which seem to be intertwined with their sexual behavior (Doornwaard, van den Eijnden, et al., 2014). Furthermore, various antecedents of the patterns of SEM use were assessed, most notably gender, age, initial level of sexual experience, sexual interest, sensation seeking, life satisfaction, depression, communication with parents, perceived realism of SEM and privacy of internet use (Doornwaard, van den Eijnden, et al., 2015, 2014; Peter \& Valkenburg, 2011c). A particularly interesting and important subject is adolescents' exposure to different SEM content and its antecedents. The study by Vandenbosch (2015) showed different degrees of adolescent exposure to affection-, dominance- and violence-themed SEM content, which were predicted by age, academic achievement and hypergendered orientation. Similar to the developmental trajectories of SEM use, adolescents may also differ in their SEM preference trajectories since contemporary SEM is characterized by unprecedented diversity (Ropelato, 2007). Although the findings by Vandenbosch (2015) and Ybarra et al. (2011) suggested that only a small minority of adolescents were exposed to violent SEM, it remains unclear whether other adolescents will eventually use violent or aggressive SEM and which demographic, socio-cultural and socio-psychological factors might predict such development. The progression to violent SEM use could be explained by the violent desensitization model (Hald, Seaman, \& Linz, 2014), according to which SEM consumers may gradually become less emotionally involved and disturbed by sexually violent content. Desensitization is then followed by normalization and acceptance of such sexual scripts, which may lead to more extreme or aggressive sexual practices. Currently, there is little evidence supporting such a (universalistic) trajectory (Seigfried-Spellar \& Rogers, 2013), and the conceptual model does 
not seem to account for the fact that not all young people may find their first exposure to violent content interesting or exciting enough to continue using it.

\section{Attitudes and Beliefs}

The reviewed studies found that SEM use or exposure may affect a range of adolescents' attitudes and beliefs, such as sexual preoccupancy (Peter \& Valkenburg, 2008a), sexual uncertainty (Peter \& Valkenburg, 2010a; van Oosten, 2015), the sexual objectification of women (Peter \& Valkenburg, 2009a), sexual satisfaction (Peter \& Valkenburg, 2009b), recreational and permissive sex attitudes (Baams et al., 2014; Brown \& L’Engle, 2009), egalitarian gender role attitudes (Brown \& L'Engle, 2009) and body surveillance (Doornwaard, Bickham, et al., 2014). Some but not all of these (bi-)directional associations of SEM use and adolescents' attitudes and beliefs were moderated by gender, confirming young people's gender-specific sexual socialization (Oliver \& Hyde, 1993).

While Peter and Valkenburg (2009b) did not find a moderating effect of gender on the association between SEM use and sexual satisfaction, an another Dutch study found that lower levels of sexual satisfaction were predicted by higher initial levels of SEM use among male adolescents and by increasing SEM use among female adolescents (Doornwaard, Bickham, et al., 2014). The contradictory findings may be due to the different indicators of sexual satisfaction used in the two studies and/or different developmental profiles of SEM use in the two samples. Discussing gender non-specific findings on sexual preoccupancy and the sexual objectification of women, Peter and Valkenburg (2008a, 2009a) suggested that the results may be different if gender was operationalized in terms of degrees of masculinity and femininity. Interestingly, in her assessment of the impact of SEM use on sexual uncertainty, van Oosten (2015) included both gender and hypergendered orientation (hyperfemininity/hypermasculinity) as moderators and found that female adolescents with a low level of hyperfemininity were more susceptible to sexual uncertainty following SEM use. 
In contrast, gender did not moderate the influence of SEM use on sexual uncertainty in the study by Peter and Valkenburg (2010a). Thus, employing multi-dimensional conceptual models that simultaneously address more than one moderating and mediating variable in the relationship between SEM use and its outcomes could lead to a better understanding of the current findings.

\section{Sexual Behavior}

A study carried out among American teenagers showed that frequent SEM use increased the likelihood of first sexual intercourse (Brown \& L'Engle, 2009). Similar results were reported in a Belgian study, but the association was moderated by pubertal status (Vandenbosch \& Eggermont, 2013). In contrast, Doornwaard and her team (2015) failed to find either direct or indirect effects of SEM use on Dutch adolescents' engagement in sexual intercourse. These inconsistencies may be related to the studies' different operational definitions of SEM and, consequently, the different measurements used. The latter two studies measured online SEM use, while Brown and L'Engle, who used a broader definition of SEM, measured the use of SEM and erotica in magazines, television and the Internet.

\section{Sexual Aggression}

Two studies showed that SEM use, particularly the consumption of violent SEM content, can increase the likelihood of sexual harassment perpetration (Brown \& L'Engle, 2009) and, in male adolescents, sexually aggressive behavior (Ybarra et al., 2011). Social desirability may have biased these findings via underreporting. Although the issue is highly sensitive and may antagonize some members of ethical review boards, more data is needed on the potential relationship between SEM use and sexual aggression in young people (Malamuth \& Huppin, 2005; Malamuth et al., 2000; Ybarra \& Mitchell, 2005). 
Limitations related to research design, lost to follow-up and non-response analysis, defining SEM use, incongruity in measuring SEM use, non-reported and/or nonproblematized effects sizes and possible cultural specificity of findings were observed.

Several studies used a two-wave design (Beyens et al., 2015; Brown \& L'Engle, 2009; Peter \& Valkenburg, 2011a, 2011b, 2011c), resulting in inconclusive causal inferences due to difficulties in distinguishing measurement errors and change in the two-wave data (Ployhart $\&$ Ward, 2011). Furthermore, the time lags between subsequent waves among the reviewed studies varied from six months to two years. This was briefly discussed in a minority of the studies (Peter \& Valkenburg, 2008a, 2009b; Vandenbosch \& Eggermont, 2013; Vandenbosch, 2015). To enable the detection of the desired effect, researchers should provide methodological and theoretical arguments for the choice of time lag between measurement points (de Lange, Taris, Kompier, Houtman, \& Bongers, 2003; Slater, 2007), as well as for the timing of particular measurements (Ployhart \& Vandenberg, 2010).

Although all the reviewed studies reported the number of participants in each wave, four of the studies did not discuss the possible reasons for lost to follow-up participants (Baams et al., 2014; Beyens et al., 2015; van Oosten, 2015; Vandenbosch \& Eggermont, 2013). Three studies did not provide information about how the problem of missing data was addressed (Baams et al., 2014; J. D. Brown \& L'Engle, 2009; van Oosten, 2015). The study by Ybarra and coauthors (2011) did not seem to carry out any bias assessment by analyzing the differences between the baseline and final samples. In contrast, Beyens and her collaborators (2015) stated that the attrition in their study resulted in an overrepresentation of participants who use SEM more frequently and of those in more advanced pubertal stages, which affected the measurement of the association between SEM use and academic performance. 
The authors of the studies used different terminology to refer to SEM: "sexually explicit media” (Brown \& L’Engle, 2009), “X-rated material” (Ybarra et al., 2011), “sexualized media” (Baams et al., 2014), "sexual media content” (Hennessy et al., 2010), “sexually explicit websites” (Beyens et al., 2015; Vandenbosch \& Eggermont, 2013) and "sexually explicit internet material" (used by several Dutch teams); these differences reflect different conceptualizations - i.e., differences in the media sources and the degree of explicitness included. Seven of the studies failed to provide a definition of SEM (Beyens et al., 2015; Doornwaard, ter Bogt, et al., 2015; Doornwaard, van den Eijnden, et al., 2015, 2014; Doornwaard, Bickham, et al., 2014; Hennessy et al., 2010; Ybarra et al., 2011). Definitions varied from focusing on sexually explicit material, such as Peter and Valkenburg's definition of SEM as “(audio-)visual content on the Internet that depicts sexual activities in unconcealed ways, often with close-ups of (aroused) genitals and of oral, anal, and vaginal penetration" (2008a, p. 208), to including nudity and erotica (Brown \& L'Engle, 2009; Baams et al., 2014). Recent reviews of mostly cross-sectional research on Internet pornography highlighted the same problem of inconsistent or varying definitions and conceptualizations of the studied phenomenon (Peter \& Valkenburg, 2016; Short et al., 2012). These different conceptualizations and, consequently, the different measures of SEM use render some comparisons among the studies difficult, if not impossible.

Most of effect sizes reported in the reviewed studies were small, especially when structural equation modeling was employed. However, this may be misleading. Recently, Adachi and Willoughby (2014) warned against a straightforward interpretation of a small effect size obtained in panel studies. Beside proposing a lower cut-off for potentially meaningful effect sizes in longitudinal studies $(\beta>.05)$, they also suggested that researchers should always discuss effect size and its potential attenuation in the context of the stability effect (i.e., whether a predictor affects the outcome over time when controlling for previous 
levels of the outcome) and the size of bivariate correlations between predictors and outcomes. Only three of the reviewed studies included any discussion of the observed effect sizes (Peter \& Valkenburg, 2009b, 2010a, 2010b).

Finally, taking into account that the studies included in this report were conducted in three highly developed Western countries characterized by substantial levels of sexual permissiveness (Hofstede, 2001; Peter \& Valkenburg, 2016; Schalet, 2000), the generalizability of their findings remains limited.

Future research needs to take into account the above limitations. In addition, several recommendations can be briefly outlined: Researchers should employ systematic efforts and pre-designed strategies to minimize attrition rates. If they are not classroom-based or do not use a commercial youth panel, longitudinal sexuality-related studies among adolescents suffer from substantial attrition (Kuyper, De Wit, Adam, \& Woertman, 2012; Zimmer-Gembeck \& Helfand, 2008), with younger samples being characterized by a more pronounced gradual loss of participants than older samples. ${ }^{\ddagger}$ Researchers should plan for and use a number of attrition reducing strategies beyond providing incentives (most often lottery-based) for participation. For example, Ladin L'Engle, Pardun and Brown (2004) recommended branding a study by developing an appealing, easy-to-remember name and a visually captivating identity of the research material (leaflets, registration web-page, project's Facebook page, etc.). In the case

\footnotetext{
$\$$ To avoid the substantial attrition rates characteristic of online panels, researchers usually resort to classroombased data collection, as was the case with a several of the reviewed studies. The notable advantages of this approach (easy access to participants, on-site monitoring of the data collection process and the possibility to clarify questionnaire material) need to be weighed against the potential challenges, such as gaining approval from school principals and achieving privacy and confidentiality (Ladin L'Engle et al., 2004). In research on sensitive issues, participants' worries over confidentiality remain a central threat to data validity (Lothen-Kline, Howard, Hamburger, Worrell, \& Boekeloo, 2003; Singer, Hippler, \& Schwarz, 1992).
} 
of (non-commercial) online panels, designing a user-friendly and "hip" website, as well as keeping in touch with participants throughout the data collection period by creatively using online social networks and other means of Internet communication, may increase adolescents' interest and help in developing commitment to the study. Developing a popular cell phone application that would also serve as a platform for repeated surveys may be an unattainable goal, but it is a reminder of the importance of creativity in maintaining online panels with adolescents.

The question of assessing different types of SEM or specific SEM content remains open both conceptually and methodologically. This issue was also highlighted in recent reviews (Owens et al., 2012; Peter \& Valkenburg, 2016). Although two studies examined content-specific SEM use among adolescents (Vandenbosch, 2015; Ybarra et al., 2011), more research is needed to explore the possible ties between the use of specific SEM and a number of adverse outcomes (cf. Malamuth \& Huppin, 2005). Two difficulties are currently impeding such efforts: the absence of validated measures of adolescents' SEM preferences and the resistance of some ethical review boards to the idea of asking adolescents detailed questions about their SEM use.

A recent overview of cross-sectional studies pointed to contradicting findings on the association between sexual risk taking and SEM use among adolescents (Owens et al., 2012). Future longitudinal research could substantially contribute to this important debate by employing multiple indicators of (self-reported) sexual risk taking and by including, whenever feasible, objective measures (de Lange et al., 2003). For example, non-invasive biological data collection, such as salivary testosterone testing (Shirtcliff, Dahl, \& Pollak, 2009) or urine-based Chlamydia trachomatis testing (Božičević et al., 2011), could be used to measure participants' pubertal status and sexual risk taking, respectively. 
Perceived peer norms and behaviors seem to be stable predictors of adolescents' sexual behavior or intention (Buhi \& Goodson, 2007), and a recent study by Vanden Abeele, Campbell, Eggermont and Roe (2014) has showed that perceived peer pressure among male adolescents predicted SEM use on portable Internet devices. To further the understanding of adolescents' peer-embedded social context, its dynamics and the potential influence on SEM use, researchers are encouraged to employ social network analysis, which is missing from the current longitudinal research. This analytical method has proven itself useful in (sexual) health-related research among adolescents (Bearman, Moody, \& Stovel, 2004; Fichtenberg et al., 2009; Smith \& Christakis, 2008). The ego-centered social network analysis might be a particularly useful approach in exploring the role of adolescent peer network characteristics in the association between SEM use and various outcomes.

The possible positive effects of SEM use remain under-researched (Peter \& Valkenburg, 2016). Although such a research agenda may seem controversial in the current hyper-vigilant climate over SEM-related harms, researchers should also examine positive behavioral and non-behavioral outcomes and contextualize them within the adolescent sexual health and well-being framework (Fortenberry, 2016). Exploring the associations between SEM use and information about sexual pleasure and well-being, attention paid to partner's sexual experience, open communication about sexuality-related issues with a partner and tolerance toward sexual minorities would contribute to the current understanding of sexual development in adolescence.

Only a few of the findings reviewed here have been replicated: the influence of SEM use on adolescents' sexual initiation (Brown \& L'Engle, 2009; Doornwaard, ter Bogt, et al., 2015; Vandenbosch \& Eggermont, 2013), sexual uncertainty (Peter \& Valkenburg, 2010a; van Oosten, 2015) and sexual permissiveness (Baams et al., 2014; Brown \& L'Engle, 2009). Any advancement in this subject area will strongly depend on the availability of replication 
studies to minimize the risk of erroneous conclusions that may have occurred due to sampling errors, sample characteristics, lack of internal validity, fraud, contextual background of the research or data collection procedures (Schmidt, 2009).

Last but not least, researchers are encouraged to conduct studies in other cultural settings to enable cross-cultural comparisons. Conducting a study in cultures with more traditional social regulation of sexuality may result in different insights regarding the outcomes of adolescent SEM use.

\section{CONCLUSIONS}

The unprecedented availability of online SEM has raised new concerns over the negative effects of SEM use, particularly among young people. In the research field dominated by cross-sectional research, longitudinal studies have the greatest potential for furthering our understanding of the possible positive and negative effects of SEM. Unfortunately, a small number of the existing longitudinal studies of adolescent SEM use are characterized by a restricted comparability as the employed diverse operationalization of SEM and the key outcomes. Not surprisingly, only a few of the reported findings have been replicated. Despite the well-known difficulties in carrying out longitudinal research (Lynn, 2014), particularly when doing research on sensitive topics (Caskey \& Rosenthal, 2005), more prospective studies are needed, followed by a meta-analytic assessment, to provide valuable insights for educators, policy makers and parents. 


\section{REFERENCES}

Adachi, P., \& Willoughby, T. (2014). Interpreting effect sizes when controlling for stability effects in longitudinal autoregressive models: Implications for psychological science. European Journal of Developmental Psychology, 12(1), 116-128. http://doi.org/10.1080/17405629.2014.963549

Alexy, E. M., Burgess, A. W., \& Prentky, R. A. (2009). Pornography use as a risk marker for an aggressive pattern of behavior among sexually reactive children and adolescents. Journal of the American Psychiatric Nurses Association, 14(6), 442-53. http://doi.org/10.1177/1078390308327137

Baams, L., Overbeek, G., Dubas, J. S., Doornwaard, S. M., Rommes, E., \& van Aken, M. A. G. (2014). Perceived Realism Moderates the Relation Between Sexualized Media Consumption and Permissive Sexual Attitudes in Dutch Adolescents. Archives of Sexual Behavior. http://doi.org/10.1007/s10508-014-0443-7

Bearman, P. S., Moody, J., \& Stovel, K. (2004). Chains of Affection: The Structure of Adolescent Romantic and Sexual Networks. American Journal of Sociology, 110(1), 4491. http://doi.org/10.1086/386272

Beyens, I., Vandenbosch, L., \& Eggermont, S. (2015). Early Adolescent Boys' exposure to Internet pornography: Relationships to pubertal timing, sensation seeking, and academic performance. The Journal of Early Adolescence, 20, 1-32. http://doi.org/10.1177/0272431613511332

Božičević, I., Grgić, I., Židovec-Lepej, S., Čakalo, J.-I., Belak-Kovačević, S., Štulhofer, A., \& Begovac, J. (2011). Urine-based testing for Chlamydia trachomatis among young adults in a population-based survey in Croatia: feasibility and prevalence. BMC Public Health, 11(1), 230. http://doi.org/10.1186/1471-2458-11-230

Braun-Courville, D. K., \& Rojas, M. (2009). Exposure to sexually explicit Web sites and 
adolescent sexual attitudes and behaviors. The Journal of Adolescent Health : Official Publication of the Society for Adolescent Medicine, 45(2), 156-62. http://doi.org/10.1016/j.jadohealth.2008.12.004

Breakwell, G. M., \& Millward, L. J. (1997). Sexual self-concept and sexual risk-taking. Journal of Adolescence, 20(1), 29-41. http://doi.org/10.1006/jado.1996.0062

Brown, J. D., Keller, S., \& Stern, S. (2008). Sex, Sexuality, Sexting, and SexEd: Adolescents and the Media. Prevention Researcher, 16(4), 12-16. Retrieved from http://eric.ed.gov/?id=EJ866789

Brown, J. D., \& L'Engle, K. L. (2009). X-Rated: Sexual Attitudes and Behaviors Associated With U.S. Early Adolescents' Exposure to Sexually Explicit Media. Communication Research, 36, 129-151. http://doi.org/10.1177/0093650208326465

Buhi, E. R., \& Goodson, P. (2007). Predictors of adolescent sexual behavior and intention: a theory-guided systematic review. The Journal of Adolescent Health : Official Publication of the Society for Adolescent Medicine, 40(1), 4-21. http://doi.org/10.1016/j.jadohealth.2006.09.027

Caskey, J. D., \& Rosenthal, S. L. (2005). Conducting research on sensitive topics with adolescents: ethical and developmental considerations. Journal of Developmental and Behavioral Pediatrics : JDBP, 26(1), 61-7. Retrieved from http://www.ncbi.nlm.nih.gov/pubmed/15718886

Collins, R. L., Martino, S., \& Shaw, R. (2011). Influence of New Media on Adolescent Sexual Health. RAND Corporation. Retrieved from http://www.rand.org/pubs/working_papers/WR761.html

Cooper, A. (1998). Sexuality and the Internet: Surfing into the New Millennium. CyberPsychology \& Behavior, 1(2), 187-193. http://doi.org/10.1089/cpb.1998.1.187 de Lange, A. H., Taris, T. W., Kompier, M. A. J., Houtman, I. L. D., \& Bongers, P. M. 
(2003). "The very best of the millennium": longitudinal research and the demandcontrol-(support) model. Journal of Occupational Health Psychology, 8(4), 282-305. http://doi.org/10.1037/1076-8998.8.4.282

Doornwaard, S. M., Bickham, D. S., Rich, M., Vanwesenbeeck, I., van den Eijnden, R. J. J. M., \& ter Bogt, T. F. M. (2014). Sex-Related Online Behaviors and Adolescents ' Body and Sexual Self-Perceptions. Pediatrics, 134(6), 1103-1110. http://doi.org/10.1542/peds.2014-0592

Doornwaard, S. M., ter Bogt, T. F. M., Reitz, E., \& van den Eijnden, R. J. J. M. (2015). SexRelated Online Behaviors, Perceived Peer Norms and Adolescents' Experience with Sexual Behavior: Testing an Integrative Model. PloS One, 10(6), e0127787. http://doi.org/10.1371/journal.pone.0127787

Doornwaard, S. M., van den Eijnden, R. J. J. M., Baams, L., Vanwesenbeeck, I., \& ter Bogt, T. F. M. (2015). Lower Psychological Well-Being and Excessive Sexual Interest Predict Symptoms of Compulsive Use of Sexually Explicit Internet Material Among Adolescent Boys. Journal of Youth and Adolescence, 45(1), 73-84. http://doi.org/10.1007/s10964015-0326-9

Doornwaard, S. M., van den Eijnden, R. J. J. M., Overbeek, G., \& Ter Bogt, T. F. M. (2014). Differential developmental profiles of adolescents using sexually explicit internet material. Journal of Sex Research, (December 2014), 37-41. http://doi.org/10.1080/00224499.2013.866195

Döring, N. M. (2009). The Internet's impact on sexuality: A critical review of 15 years of research. Computers in Human Behavior, 25(5), 1089-1101. http://doi.org/10.1016/j.chb.2009.04.003

Fichtenberg, C. M., Muth, S. Q., Brown, B., Padian, N. S., Glass, T. A., \& Ellen, J. M. (2009). Sexual network position and risk of sexually transmitted infections. Sexually 
Transmitted Infections, 85(7), 493-8. http://doi.org/10.1136/sti.2009.036681

Fortenberry, J. D. (2016). Adolescent Sexual Well-being in the 21st Century. The Journal of Adolescent Health : Official Publication of the Society for Adolescent Medicine, 58(1), 1-2. http://doi.org/10.1016/j.jadohealth.2015.10.250

Häggström-Nordin, E., Sandberg, J., Hanson, U., \& Tydén, T. (2006). “It”s everywhere!' Young Swedish people's thoughts and reflections about pornography. Scandinavian Journal of Caring Sciences, 20(4), 386-393. http://doi.org/10.1111/j.14716712.2006.00417.x

Hald, G. M., Kuyper, L., Adam, P. C. G., \& de Wit, J. B. F. (2013). Does viewing explain doing? Assessing the association between sexually explicit materials use and sexual behaviors in a large sample of Dutch adolescents and young adults. The Journal of Sexual Medicine, 10(12), 2986-95. http://doi.org/10.1111/jsm.12157

Hald, G. M., Seaman, C., \& Linz, D. (2014). Sexuality and pornography. In D. Tolman, L. Diamond, J. Bauermeister, W. George, J. Pfaus, \& M. Ward (Eds.), APA handbook of sexuality and psychology. Contextual approaches (pp. 3-35). Washington, DC: American Psychological Association.

Hennessy, M., Bleakley, A., Fishbein, M., \& Jordan, A. (2010). Estimating the longitudinal association between adolescent sexual behavior and exposure to sexual media content. Journal of Sex Research, 46(6), 586-596. http://doi.org/10.1080/00224490902898736.Estimating

Hofstede, G. (2001). Culture's consequences: Comparing values, behaviours, institutions and organizations across nations. Thousand Oaks, CA: Sage Publications.

Horvath, M., Alys, L., Massey, K., Pina, A., Scally, M., \& Adler, J. R. (2013). "Basically...porn is everywhere". A Rapid Evidence Assessment on the Effects that Access and Exposure to Pornography has on Children and Young People. Office of the 
Children's Commissioner. Retrieved from

http://kar.kent.ac.uk/44763/1/BasicallyporniseverywhereReport.pdf

Iceland seeks internet pornography ban. (2013, February 25). Retrieved from

http://www.theguardian.com/world/2013/feb/25/iceland-seeks-internet-pornography-ban

Klaassen, M. J. E., \& Peter, J. (2015). Gender (In)equality in Internet Pornography: A Content Analysis of Popular Pornographic Internet Videos. Journal of Sex Research, 52(7), 72135. http://doi.org/10.1080/00224499.2014.976781

Klettke, B., Hallford, D. J., \& Mellor, D. J. (2014). Sexting prevalence and correlates: A systematic literature review. Clinical Psychology Review, 34(1), 44-53. http://doi.org/10.1016/j.cpr.2013.10.007

Kreiger, T. C., \& Dumka, L. E. (2006). The Relationships Between Hypergender, Gender, and Psychological Adjustment. Sex Roles, 54(11-12), 777-785. http://doi.org/10.1007/s11199-006-9044-9

Kuyper, L., De Wit, J., Adam, P., \& Woertman, L. (2012). Doing more good than harm? the effects of participation in sex research on young people in the Netherlands. Archives of Sexual Behavior, 41(2), 497-506. http://doi.org/10.1007/s10508-011-9780-y

Ladin L'Engle, K., Pardun, C. J., \& Brown, J. D. (2004). Accessing Adolescents: A SchoolRecruited, Home-Based Approach to Conducting Media and Health Research. Journal of Early Adolescence, 24(2), 144-158. http://doi.org/10.1177/0272431603262668

Löfgren-Mårtenson, L., \& Månsson, S.-A. (2010). Lust, Love, and Life: A Qualitative Study of Swedish Adolescents' Perceptions and Experiences with Pornography. Journal of Sex Research, 47(6), 568-579. http://doi.org/10.1080/00224490903151374

Lothen-Kline, C., Howard, D. E., Hamburger, E. K., Worrell, K. D., \& Boekeloo, B. O. (2003). Truth and consequences: Ethics, confidentiality, and disclosure in adolescent longitudinal prevention research. Journal of Adolescent Health, 33(5), 385-394. 
http://doi.org/10.1016/S1054-139X(03)00184-8

Luder, M.-T., Pittet, I., Berchtold, A., Akré, C., Michaud, P.-A., \& Surís, J.-C. (2011). Associations between online pornography and sexual behavior among adolescents: myth or reality? Archives of Sexual Behavior, 40(5), 1027-35. http://doi.org/10.1007/s10508010-9714-0

Lynn, P. (2014). Methodology of Longitudinal Surveys. New York: Wiley.

Malamuth, N., \& Huppin, M. (2005). Pornography and Teenagers: The Importance of Individual Differences. Adolescent Medicine Clinics, 16, 315-326. http://doi.org/10.1016/j.admecli.2005.02.004

Malamuth, N. M., Addison, T., \& Koss, M. (2000). Pornography and sexual aggression: are there reliable effects and can we understand them? Annual Review of Sex Research, 11, 26-91. Retrieved from http://www.ncbi.nlm.nih.gov/pubmed/11351835

Mattebo, M., Tydén, T., Häggström-Nordin, E., Nilsson, K. W., \& Larsson, M. (2013). Pornography consumption, sexual experiences, lifestyles, and self-rated health among male adolescents in Sweden. Journal of Developmental and Behavioral Pediatrics : JDBP, 34(7), 460-8. http://doi.org/10.1097/DBP.0b013e31829c44a2

Murnen, S. K., \& Byrne, D. (1991). Hyperfemininity: Measurement and initial validation of the construct. Journal of Sex Research, 28(3), 479-489. http://doi.org/10.1080/00224499109551620

Oliver, M. B., \& Hyde, J. S. (1993). Gender differences in sexuality: a meta-analysis. Psychological Bulletin, 114(1), 29-51. Retrieved from http://www.ncbi.nlm.nih.gov/pubmed/8346327

Online pornography to be blocked by default, PM announces. (2013, July 22). Retrieved from http://www.bbc.com/news/uk-23401076

Owens, E. W., Behun, R. J., Manning, J. C., \& Reid, R. C. (2012). The Impact of Internet 
Pornography on Adolescents: A Review of the Research. Sexual Addiction \& Compulsivity, 19, 99-122. http://doi.org/10.1080/10720162.2012.660431

Peter, J., \& Valkenburg, P. M. (2006a). Adolescents' Exposure to Sexually Explicit Material on the Internet. Communication Research, 33(2), 178-204. http://doi.org/10.1177/0093650205285369

Peter, J., \& Valkenburg, P. M. (2006b). Adolescents’ Exposure to Sexually Explicit Online Material and Recreational Attitudes Toward Sex. Journal of Communication, 56(October 2015), 639-660. http://doi.org/10.1111/j.1460-2466.2006.00313.x

Peter, J., \& Valkenburg, P. M. (2007). Adolescents' Exposure to a Sexualized Media Environment and Their Notions of Women as Sex Objects. Sex Roles, 56, 381-395. http://doi.org/10.1007/s11199-006-9176-y

Peter, J., \& Valkenburg, P. M. (2008a). Adolescents' Exposure to Sexually Explicit Internet Material and Sexual Preoccupancy: A Three-Wave Panel Study. Media Psychology, 11(2), 207-234. http://doi.org/10.1080/15213260801994238

Peter, J., \& Valkenburg, P. M. (2008b). Adolescents' Exposure to Sexually Explicit Internet Material, Sexual Uncertainty, and Attitudes Toward Uncommitted Sexual Exploration: Is There a Link? Communication Research, 35(5), 579-601. http://doi.org/10.1177/0093650208321754

Peter, J., \& Valkenburg, P. M. (2009a). Adolescents’ Exposure to Sexually Explicit Internet Material and Notions of Women as Sex Objects: Assessing Causality and Underlying Processes. Journal of Communication, 59(3), 407-433. http://doi.org/10.1111/j.14682958.2009.01343.x

Peter, J., \& Valkenburg, P. M. (2009b). Adolescents' exposure to sexually explicit internet material and sexual satisfaction: A longitudinal study. Human Communication Research, 35, 171-194. http://doi.org/10.1111/j.1468-2958.2009.01343.x 
Peter, J., \& Valkenburg, P. M. (2010a). Adolescents' Use of Sexually Explicit Internet Material and Sexual Uncertainty: The Role of Involvement and Gender. Communication Monographs, 77(3), 357-375. http://doi.org/10.1080/03637751.2010.498791

Peter, J., \& Valkenburg, P. M. (2010b). Processes Underlying the Effects of Adolescents' Use of Sexually Explicit Internet Material: The Role of Perceived Realism. Communication Research, 37, 375-399. http://doi.org/10.1177/0093650210362464

Peter, J., \& Valkenburg, P. M. (2011a). The influence of sexually explicit Internet material and peers on stereotypical beliefs about women's sexual roles: similarities and differences between adolescents and adults. Cyberpsychol Behav Soc Netw, 14(9), 511517. http://doi.org/10.1089/cyber.2010.0189

Peter, J., \& Valkenburg, P. M. (2011b). The influence of sexually explicit Internet material on sexual risk behavior: a comparison of adolescents and adults. Journal of Health Communication, 16, 750-765. http://doi.org/10.1080/10810730.2011.551996

Peter, J., \& Valkenburg, P. M. (2011c). The use of sexually explicit internet material and its antecedents: A longitudinal comparison of adolescents and adults. Archives of Sexual Behavior, 40, 1015-1025. http://doi.org/10.1007/s10508-010-9644-х

Peter, J., \& Valkenburg, P. M. (2014). Does exposure to sexually explicit Internet material increase body dissatisfaction? A longitudinal study. Computers in Human Behavior, 36, 297-307. http://doi.org/10.1016/j.chb.2014.03.071

Peter, J., \& Valkenburg, P. M. (2016). Adolescents and Pornography: A Review of 20 Years of Research. The Journal of Sex Research, 53(4-5), 1-23. http://doi.org/10.1080/00224499.2016.1143441

Petley, J. (2014). The regulation of pornography on video-on-demand in the United Kingdom. Porn Studies, 1(3), 260-284. http://doi.org/10.1080/23268743.2014.927705 Ployhart, R. E., \& Ward, A.-K. (2011). The “Quick Start Guide” for Conducting and 
Publishing Longitudinal Research. Journal of Business and Psychology, 26(4), 413-422. http://doi.org/10.1007/s10869-011-9209-6

Ployhart, R., \& Vandenberg, R. (2010). Longitudinal Research: The Theory,Design, and Analysis of Change. Journal of Management, 36(1), 94-120. http://doi.org/10.1177/0149206309352110

Ropelato, J. (2007). Internet pornography statistics. Retrieved January 5, 2016, from http://internet-filter-review.toptenreviews.com/internet-pornography-statistics.html Sabina, C., Wolak, J., \& Finkelhor, D. (2008). The Nature and Dynamics of Internet Pornography Exposure for Youth. CyberPsychology \& Behavior, 11(6), 691-693. http://doi.org/10.1089/cpb.2007.0179

Schalet, A. T. (2000). Raging Hormones, Regulated Love: Adolescent Sexuality and the Constitution of the Modern Individual in the United States and the Netherlands. Body \& Society, 6(1), 75-105. http://doi.org/10.1177/1357034X00006001006

Schmidt, S. (2009). Shall we really do it again? The powerful concept of replication is neglected in the social sciences. Review of General Psychology, 13(2), 90-100. http://doi.org/10.1037/a0015108

Seigfried-Spellar, K. C., \& Rogers, M. K. (2013). Does deviant pornography use follow a Guttman-like progression? Computers in Human Behavior, 29(5), 1997-2003. http://doi.org/10.1016/j.chb.2013.04.018

Shadish, W. R., Cook, T. D., \& Campbell, D. T. (2002). Experimental and QuasiExperimental Designs for Generalized Causal Inference. Boston, MA: Houghton Mifflin.

Shirtcliff, E. A., Dahl, R. E., \& Pollak, S. D. (2009). Pubertal development: correspondence between hormonal and physical development. Child Development, 80(2), 327-37. http://doi.org/10.1111/j.1467-8624.2009.01263.x 
Short, M. B., Black, L., Smith, A. H., Wetterneck, C. T., \& Wells, D. E. (2012). A review of Internet pornography use research: methodology and content from the past 10 years. Cyberpsychology, Behavior and Social Networking, 15(1), 13-23.

Singer, E., Hippler, H.-J., \& Schwarz, N. (1992). Confidentiality Assurances in Surveys: Reassurance or Threat? International Journal of Public Opinion Research, 4(3), 256268. http://doi.org/10.1093/ijpor/4.3.256

Slater, M. D. (2007). Reinforcing spirals: The mutual influence of media selectivity and media effects and their impact on individual behavior and social identity. Communication Theory, 17(3), 281-303. http://doi.org/10.1111/j.14682885.2007.00296.x

Smith, K. P., \& Christakis, N. A. (2008). Social Networks and Health. Annual Review of Sociology, 34, 405-418. http://doi.org/10.1146/annurev.soc.34.040507.134601

Stulhofer, A., Busko, V., \& Landripet, I. (2010). Pornography, sexual socialization, and satisfaction among young men. Archives of Sexual Behavior, 39(1), 168-78. http://doi.org/10.1007/s10508-008-9387-0

Svedin, C. G., Åkerman, I., \& Priebe, G. (2011). Frequent users of pornography. A population based epidemiological study of Swedish male adolescents. Journal of Adolescence, 34(4), 779-788. http://doi.org/10.1016/j.adolescence.2010.04.010

Ševčíková, A., \& Daneback, K. (2014). Online pornography use in adolescence: Age and gender differences. European Journal of Developmental Psychology, 11(6), 674-686. http://doi.org/10.1080/17405629.2014.926808

van Oosten, J. M. F. (2015). Sexually Explicit Internet Material and Adolescents' Sexual Uncertainty: The Role of Disposition-Content Congruency. Archives of Sexual Behavior. http://doi.org/10.1007/s10508-015-0594-1

Vanden Abeele, M., Campbell, S. W., Eggermont, S., \& Roe, K. (2014). Sexting, Mobile 
Porn Use, and Peer Group Dynamics: Boys' and Girls' Self-Perceived Popularity, Need for Popularity, and Perceived Peer Pressure. Media Psychology, 17(1), 6-33. http://doi.org/10.1080/15213269.2013.801725

Vandenbosch, L. (2015). Antecedents of adolescents' exposure to different types of sexually explicit Internet material: A longitudinal study. Computers in Human Behavior, 50, 439448. http://doi.org/10.1016/j.chb.2015.04.032

Vandenbosch, L., \& Eggermont, S. (2013). Sexually Explicit Websites and Sexual Initiation: Reciprocal Relationships and the Moderating Role of Pubertal Status. Journal of Research on Adolescence, 23, 621-634. http://doi.org/10.1111/jora.12008

Weber, M., Quiring, O., \& Daschmann, G. (2012). Peers, Parents and Pornography: Exploring Adolescents' Exposure to Sexually Explicit Material and Its Developmental Correlates. Sexuality \& Culture, 16(4), 408-427. http://doi.org/10.1007/s12119-012-9132-7

Whittaker, Z. (2013, March 12). EU votes to reject "porn ban" proposals. Retrieved from http://www.cnet.com/news/eu-votes-to-reject-porn-ban-proposals/

Will porn be banned in Europe? EU set to vote on internet crackdown. (2013, March 8). Retrieved from http://www.dailymail.co.uk/news/article-2290270/Will-porn-bannedEurope-EU-set-vote-internet-crackdown.html

Wingood, G. M., DiClemente, R. J., Harrington, K., Davies, S., Hook, E. W., \& Oh, M. K. (2001). Exposure to X-rated movies and adolescents' sexual and contraceptive-related attitudes and behaviors. Pediatrics, 107(5), 1116-9. Retrieved from http://www.ncbi.nlm.nih.gov/pubmed/11331695

Winter, L. (1988). The role of sexual self-concept in the use of contraceptives. Family Planning Perspectives, 20(3), 123-127. Retrieved from http://www.ncbi.nlm.nih.gov/pubmed/3417002

Wolak, J., Mitchell, K., \& Finkelhor, D. (2007). Unwanted and wanted exposure to online 
pornography in a national sample of youth Internet users. Pediatrics, 119(2), 247-57. http://doi.org/10.1542/peds.2006-1891

Wright, P. J. (2012). A Longitudinal Analysis of US Adults' Pornography Exposure. Journal of Media Psychology, 24(2), 67-76. http://doi.org/10.1027/1864-1105/a000063

Ybarra, M. L., \& Mitchell, K. J. (2005). Exposure to Internet Pornography among Children and Adolescents: A National Survey. CyberPsychology \& Behavior, 8(5), 473-486. http://doi.org/10.1089/cpb.2005.8.473

Ybarra, M. L., Mitchell, K. J., Hamburger, M., Diener-West, M., \& Leaf, P. J. (2011). X-rated material and perpetration of sexually aggressive behavior among children and adolescents: Is there a link? Aggressive Behavior, 37(1), 1-18. http://doi.org/10.1002/ab.20367

Zimmer-Gembeck, M. J., \& Helfand, M. (2008). Ten years of longitudinal research on U.S. adolescent sexual behavior: Developmental correlates of sexual intercourse, and the importance of age, gender and ethnic background. Developmental Review, 28(2), 153224. http://doi.org/10.1016/j.dr.2007.06.001 


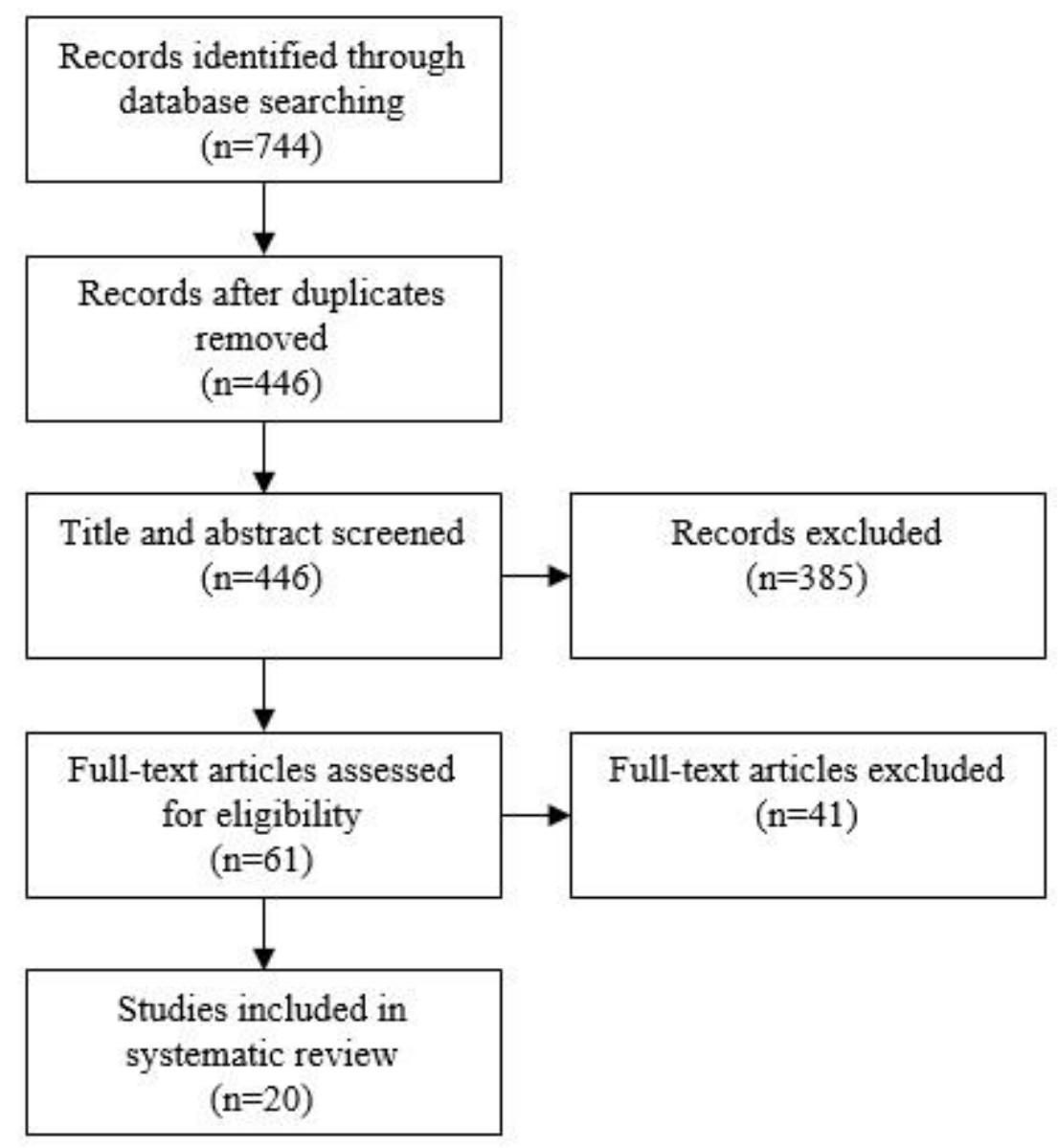

Figure 1. Study Selection Flowchart 
Table 1

Details of the Selected Research Projects

\begin{tabular}{|c|c|c|c|c|c|c|c|c|}
\hline ID & Authors & Country & Fieldwork started & No of waves & Interval & Data collection & Recruitment & Papers published \\
\hline 1 & $\begin{array}{l}\text { Baams, Overbeek, } \\
\text { Dubas, Doornwaard, } \\
\text { Rommes, \& van Aken }\end{array}$ & The Netherlands & 2009 & 3 & 6 months & $\begin{array}{c}\text { Paper and pen } \\
\text { (Classroom setting) }\end{array}$ & Classroom-based & 1 \\
\hline 2 & Brown, L'Engle & USA & 2001 & 2 & 2 years & Audio-CASI & Classroom-based & 1 \\
\hline 3 & $\begin{array}{l}\text { Doornwaard, van der } \\
\text { Eijnden, Overbeek, ter } \\
\text { Bogt, Bickham, Rich, } \\
\text { \& Vanwesenbeeck } \\
\text { (Project "STARS") }\end{array}$ & The Netherlands & 2011 & 4 & 6 months & $\begin{array}{c}\text { Web-survey } \\
\text { (Classroom setting) }\end{array}$ & Classroom-based & 4 \\
\hline 4 & $\begin{array}{l}\text { Hennessy, Bleakly, } \\
\text { Fishbein, \& Jordan }\end{array}$ & USA & 2005 & 3 & 1 year & Web-survey & $\begin{array}{l}\text { Printed and radio } \\
\text { advertisements, } \\
\text { direct mail, word of } \\
\text { mouth }\end{array}$ & 1 \\
\hline 5 & $\begin{array}{l}\text { van Oosten \& } \\
\text { Vandenbosch }\end{array}$ & The Netherlands & 2013 & 3 & 6 months & Web-survey & Commercial poll & 2 \\
\hline 6 & Peter \& Valkenburg & The Netherlands & 2006 & 3 & 6 months & Web-survey & Commercial poll & 5 \\
\hline 7 & Peter \& Valkenburg & The Netherlands & 2008 & 2 & 6 months & Web-survey & Commercial poll & 3 \\
\hline 8 & $\begin{array}{l}\text { Vandenbosch, } \\
\text { Eggermont, \& Beyens }\end{array}$ & Belgium & 2010 & 2 & 6 months & $\begin{array}{c}\text { Paper and pen } \\
\text { (Classroom setting) }\end{array}$ & Classroom-based & 2 \\
\hline 9 & $\begin{array}{l}\text { Ybarra, Mitchell, } \\
\text { Hamburger, Diener- } \\
\text { West, \& Leaf }\end{array}$ & USA & 2006 & 3 & 1 year & Web-survey & Commercial poll & 1 \\
\hline
\end{tabular}


Table 2

Characteristics of the Individual Studies in this Review

\begin{tabular}{|c|c|c|c|c|c|c|c|c|}
\hline $\begin{array}{l}\text { Research } \\
\text { project } \\
\text { ID }\end{array}$ & $\begin{array}{c}\text { Authors } \\
\text { (publication year) }\end{array}$ & $\begin{array}{c}\text { Sample } \\
\text { demographics }\end{array}$ & $\begin{array}{c}\text { SEM } \\
\text { definition }\end{array}$ & Outcome & Mediators & Moderators & Key findings & $\begin{array}{c}\text { Effect size } \\
{[\text { Data analysis] }}\end{array}$ \\
\hline 1 & $\begin{array}{l}\text { Baams, Overbeek, } \\
\text { Dubas, } \\
\text { Doornwaard, } \\
\text { Rommes, \& van } \\
\text { Aken } \\
(2014)\end{array}$ & $\begin{array}{l}\mathrm{N}=444 \text { (final) } \\
\text { Age: } 13-16 \text { (Mean } \\
=13.9) \\
\text { Male: } 48 \%\end{array}$ & Yes & $\begin{array}{l}\text { Permissive } \\
\text { sexual } \\
\text { attitudes }\end{array}$ & - & $\begin{array}{l}\text { Gender } \\
\text { Perceived } \\
\text { realism }\end{array}$ & $\begin{array}{l}\text { - Initial level of sexual media consumption was associated } \\
\text { with initial level of permissive attitudes } \\
\text { - Developmental changes of sexual media consumption } \\
\text { and permissive attitudes were positively associated } \\
\text { - Initial level of sexual media consumption was negatively } \\
\text { associated with the development of permissive attitudes } \\
\text { - Initial levels of sexual media consumption and } \\
\text { permissive attitudes were positively associated for low } \\
\text { and high perceived realism } \\
\text { - Developmental changes of sexual media consumption } \\
\text { and permissive attitudes were positively associated for } \\
\text { high perceived realism }\end{array}$ & $\begin{array}{l}\beta=0.59^{* * *} \\
\beta=0.33^{* * *} \\
\beta=-0.34^{* *}(\mathrm{M}) \\
\beta=0.56^{* * *} ; \beta=0.60^{* * *} \\
\beta=0.37 * * * \\
{[\text { Latent growth modeling] }}\end{array}$ \\
\hline 7 & $\begin{array}{l}\text { Beyens, } \\
\text { Vandenbosch, \& } \\
\text { Eggermont } \\
(2015)\end{array}$ & $\begin{array}{l}\mathrm{N}=325 \\
\text { Age: } 12-15 \text { (Mean } \\
=14.1) \\
\text { Male: } 100 \%\end{array}$ & No & $\begin{array}{l}\text { Academic } \\
\text { performance }\end{array}$ & $\begin{array}{l}\text { Sensation } \\
\text { seeking }\end{array}$ & $\begin{array}{l}\text { Pubertal } \\
\text { stage }\end{array}$ & $\begin{array}{l}\text { - Sensation seeking predicted SEM use } \\
\text { - Pubertal stage predicted SEM use } \\
\text { - SEM use predicted lower academic performance }\end{array}$ & $\begin{array}{l}\beta=0.12^{*} \\
\beta=0.15^{* *} \\
\beta=-0.09^{*} \\
{[\text { Path analysis }]}\end{array}$ \\
\hline 2 & $\begin{array}{l}\text { Brown \& L'Engle } \\
\text { (2009) }\end{array}$ & $\begin{array}{l}\mathrm{N}=967 \\
\text { Age: } 12-14 \text { (Mean } \\
=13.6) \\
\text { Male: } 50 \%\end{array}$ & Yes & $\begin{array}{l}\text { Permissive } \\
\text { sexual } \\
\text { norms } \\
\text { Progressive } \\
\text { gender role } \\
\text { attitudes } \\
\text { Sexual } \\
\text { harassment } \\
\text { perpetration } \\
\text { Oral sex } \\
\text { Sexual } \\
\text { intercourse }\end{array}$ & - & Gender & $\begin{array}{l}\text { - SEM use predicted permissive sexual norms } \\
\text { - SEM use predicted progressive gender role attitudes } \\
\text { - SEM use predicted sexual harassment } \\
\text { - SEM use predicted engagement in oral sex } \\
\text { - SEM use predicted engagement in sexual intercourse }\end{array}$ & $\begin{array}{l}\beta=0.13^{* *}(\mathrm{M}) \\
\beta=-0.12^{*}(\mathrm{~F}) \\
\beta=0.10^{*}(\mathrm{M}) \\
\mathrm{OR}=1.72^{* * *}(\mathrm{M}) ; \mathrm{OR}=1.49^{*}(\mathrm{~F}) \\
\mathrm{OR}=1.74 * * *(\mathrm{M}) ; \mathrm{OR}=1.50^{*}(\mathrm{~F}) \\
\text { [Hierarchical regression] } \\
\text { [Logistic regression] }\end{array}$ \\
\hline
\end{tabular}


Table 2 (continued)

\begin{tabular}{|c|c|c|c|c|c|c|c|c|}
\hline $\begin{array}{l}\text { Research } \\
\text { project } \\
\text { ID }\end{array}$ & $\begin{array}{c}\text { Authors } \\
\text { (publication year) }\end{array}$ & $\begin{array}{c}\text { Sample } \\
\text { demographics }\end{array}$ & $\begin{array}{c}\text { SEM } \\
\text { definition }\end{array}$ & Outcome & Mediators & Moderators & Key findings & $\begin{array}{c}\text { Effect size } \\
\text { [Data analysis] }\end{array}$ \\
\hline 3 & $\begin{array}{l}\text { Doornwaard, van } \\
\text { der Eijnden, } \\
\text { Overbeek, \& ter } \\
\text { Bogt } \\
(2014)\end{array}$ & $\begin{array}{l}\mathrm{N}=787 \\
\text { Age: } 12-17 \text { (Mean } \\
=14.3 \text { ) } \\
\text { Male: } 52 \%\end{array}$ & No & $\begin{array}{l}\text { SEM use } \\
\text { Sexual } \\
\text { behavior }\end{array}$ & - & & $\begin{array}{l}\text { Increasing SEM use profile predicted by: } \\
\text { - Permissive sexual attitudes } \\
\text { - Sexual interest } \\
\text { Occasional SEM use profile predicted by: } \\
\text { - Age } \\
\text { - Communication with parents } \\
\text { - Permissive sexual attitudes } \\
\text { - Sexual interest } \\
\text { - Privacy of Internet use } \\
\text { - Perceived realism } \\
\text { Decreasing SEM use profile predicted by: } \\
\text { - Age } \\
\text { - Disclosure to parents about whereabouts } \\
\text { - Permissive sexual attitudes } \\
\text { - Sexual interest } \\
\text { - Privacy of Internet use }\end{array}$ & $\begin{array}{l}\mathrm{B}=0.63 * *(\mathrm{M}) \\
\mathrm{B}=0.90^{*}(\mathrm{M}) ; \mathrm{B}=1.61(\mathrm{~F}) \\
\mathrm{B}=0.57 * *(\mathrm{M}) \\
\mathrm{B}=0.67 *(\mathrm{M}) \\
\mathrm{B}=0.70^{* *}(\mathrm{M}) \\
\mathrm{B}=1.42 * *(\mathrm{M}) ; \mathrm{B}=2.27 * * *(\mathrm{~F}) \\
\mathrm{B}=0.72 *(\mathrm{M}) \\
\mathrm{B}=0.46 *(\mathrm{M}) ; \mathrm{B}=1.11(\mathrm{~F}) \\
\mathrm{B}=0.90^{* * *}(\mathrm{M}) \\
\mathrm{B}=-0.56 *(\mathrm{M}) \\
\mathrm{B}=1.00^{* * *}(\mathrm{M}) \\
\mathrm{B}=1.95 * *(\mathrm{M}) \\
\mathrm{B}=1.06 *(\mathrm{M}) \\
{[\text { Latent class growth analyses }]}\end{array}$ \\
\hline 3 & $\begin{array}{l}\text { Doornwaard, } \\
\text { Bickham, Rich, } \\
\text { Vanwesenbeeck, } \\
\text { van der Eijnden, } \\
\text { Overbeek, ter } \\
\text { Bogt } \\
(2014)\end{array}$ & $\begin{array}{l}\mathrm{N}=1132 \\
\text { Age: } 11-17 \text { (Mean } \\
=13.9 \text { ) } \\
\text { Male: } 53 \%\end{array}$ & No & $\begin{array}{l}\text { Physical } \\
\text { self-esteem } \\
\text { Body } \\
\text { surveillance } \\
\text { Sexual } \\
\text { satisfaction }\end{array}$ & - & Gender & $\begin{array}{l}\text { - Higher initial level of SEM use predicted higher body } \\
\text { surveillance } \\
\text { - Higher initial level of SEM use predicted lower sexual } \\
\text { satisfaction } \\
\text { - Increased SEM use over time predicted lower sexual } \\
\text { satisfaction }\end{array}$ & $\begin{array}{l}\beta=0.13 *(\mathrm{M}) \\
\beta=-0.22 *(\mathrm{M}) \\
\beta=-0.13 *(\mathrm{~F}) \\
{[\text { Latent growth modeling }]}\end{array}$ \\
\hline 3 & $\begin{array}{l}\text { Doornwaard, van } \\
\text { der Eijnden, } \\
\text { Baams, } \\
\text { Vanwesenbeeck, } \\
\text { \& ter Bogt } \\
(2015)\end{array}$ & $\begin{array}{l}\mathrm{N}=251 \text { (data } \\
\text { from } 3 . \text { and } 4 \\
\text { wave) } \\
\text { Age }=11-17 \\
(\text { Mean }=15.2) \\
\text { Male }=100 \%\end{array}$ & No & $\begin{array}{l}\text { Compulsive } \\
\text { use of SEM }\end{array}$ & - & - & $\begin{array}{l}\text { - Excessive sexual interest predicted compulsive use of } \\
\text { SEM } \\
\text { - Depression predicted compulsive use of SEM }\end{array}$ & $\begin{array}{l}\mathrm{RR}=1.70(95 \% \text { CI: } 1.00,2.40) \\
\mathrm{RR}=1.34(95 \% \text { CI: } 1.04,1.64) \\
{[\text { Binomial regression }]}\end{array}$ \\
\hline 3 & $\begin{array}{l}\text { Doornwaard, ter } \\
\text { Bogt, Reitz, \& } \\
\text { van der Eijnden } \\
(2015)\end{array}$ & $\begin{array}{l}\mathrm{N}=1132 \\
\text { Age: } 11-17 \text { (Mean } \\
=13.9 \text { ) } \\
\text { Male: } 53 \%\end{array}$ & No & $\begin{array}{l}\text { Sexual } \\
\text { behavior }\end{array}$ & $\begin{array}{l}\text { Perceived } \\
\text { peer norms } \\
\text { (descriptive } \\
\text { and } \\
\text { injunctive) }\end{array}$ & Gender & $\begin{array}{l}\text { - SEM use predicted internalization of descriptive and } \\
\text { injunctive peer norms } \\
\text { - Descriptive norms predicted sexual behavior } \\
\text { - Injunctive norms predicted sexual behavior }\end{array}$ & $\begin{array}{l}\beta=0.10^{*}(\mathrm{M}) ; \beta=0.10^{*}(\mathrm{M}) \\
\beta=0.23^{* *}(\mathrm{M}) ; \beta=0.13^{*}(\mathrm{~F}) \\
\beta=0.16^{*}(\mathrm{~F}) \\
{[\text { Structural equation modeling] }} \\
\quad \text { (continued) }\end{array}$ \\
\hline
\end{tabular}


Table 2 (continued)

\begin{tabular}{|c|c|c|c|c|c|c|c|c|}
\hline $\begin{array}{l}\text { Research } \\
\text { project } \\
\text { ID }\end{array}$ & $\begin{array}{c}\text { Authors } \\
\text { (publication year) }\end{array}$ & $\begin{array}{c}\text { Sample } \\
\text { demographics }\end{array}$ & $\begin{array}{c}\text { SEM } \\
\text { definition }\end{array}$ & Outcome & Mediators & Moderators & Key findings & $\begin{array}{c}\text { Effect size } \\
{[\text { Data analysis] }}\end{array}$ \\
\hline 4 & $\begin{array}{l}\text { Hennessy, } \\
\text { Bleakly, } \\
\text { Fishbein, \& } \\
\text { Jordan } \\
(2010)\end{array}$ & $\begin{array}{l}\mathrm{N}=506 \\
\text { Age: } 14-16 \\
\text { (Mean }=\mathrm{nr}) \\
\text { Male: } 38 \%\end{array}$ & No & $\begin{array}{l}\text { Sexual } \\
\text { behavior } \\
\text { SEM } \\
\text { exposure }\end{array}$ & - & $\begin{array}{l}\text { Gender } \\
\text { Race }\end{array}$ & $\begin{array}{l}\text { - Higher initial level of sexual behavior was associated } \\
\text { with decreased SEM exposure over time }\end{array}$ & $\begin{array}{l}\mathrm{r}=-0.21^{*} \\
\mathrm{r}=-0.47^{*} \text { (Caucasians) } \\
{[\text { Structural equation modeling] }}\end{array}$ \\
\hline 5 & $\begin{array}{l}\text { van Oosten } \\
(2015)\end{array}$ & $\begin{array}{l}\mathrm{N}=1765 \text { (data } \\
\text { from } 1 . \text { and } 2 . \\
\text { wave) } \\
\text { Age: } 13-17 \\
\text { (Mean }=15.0 \text { ) } \\
\text { Male: } 50 \%\end{array}$ & Yes & $\begin{array}{l}\text { Sexual } \\
\text { uncertainty }\end{array}$ & - & $\begin{array}{l}\text { Gender } \\
\text { Impersonal sex } \\
\text { orientation } \\
\text { Hypergendered } \\
\text { orientation }\end{array}$ & $\begin{array}{l}\text { - Impersonal sex orientation predicted sexual uncertainty } \\
\text { - Hypergendered orientation predicted sexual } \\
\text { uncertainty }\end{array}$ & $\begin{array}{l}\beta=0.11^{*}(\mathrm{~F}) \\
\beta=-0.15^{*}(\mathrm{~F}) \\
{[\text { Multiple regression] }}\end{array}$ \\
\hline 6 & $\begin{array}{l}\text { Peter \& } \\
\text { Valkenburg } \\
\text { (2008a) }\end{array}$ & $\begin{array}{l}\mathrm{N}=962 \\
\text { Age: } 13-20 \\
\text { (Mean }=16.8) \\
\text { Male: } 49 \%\end{array}$ & Yes & $\begin{array}{l}\text { Sexual } \\
\text { preoccupancy }\end{array}$ & $\begin{array}{l}\text { Subjective } \\
\text { sexual } \\
\text { arousal }\end{array}$ & Gender & $\begin{array}{l}\text { - SEM use predicted sexual preoccupancy } \\
\text { - SEM use predicted subjective sexual arousal } \\
\text { - Subjective sexual arousal predicted sexual } \\
\text { preoccupancy }\end{array}$ & $\begin{array}{l}\beta=0.12^{* * *} \\
\beta=0.18^{* * *} \\
\beta=0.07^{*} \\
{[\text { Structural equation modeling] }}\end{array}$ \\
\hline 6 & $\begin{array}{l}\text { Peter \& } \\
\text { Valkenburg } \\
\text { (2009a) }\end{array}$ & $\begin{array}{l}\mathrm{N}=962 \\
\text { Age: } 13-20 \\
\text { (Mean }=16.8) \\
\text { Male: } 49 \%\end{array}$ & Yes & $\begin{array}{l}\text { Notions of } \\
\text { women as } \\
\text { sex objects }\end{array}$ & $\begin{array}{l}\text { Liking of } \\
\text { SEM }\end{array}$ & Gender & $\begin{array}{l}\text { - SEM use predicted the objectification of women and } \\
\text { vice versa } \\
\text { - SEM use predicted liking of SEM } \\
\text { - Liking of SEM predicted the sexual objectification of } \\
\text { women } \\
\text { - Sexual objectification of women predicted liking of } \\
\text { SEM } \\
\text { - Liking of SEM predicted SEM use }\end{array}$ & $\begin{array}{l}\beta=0.15^{* * *} ; \beta=0.09^{* *}(\mathrm{M}) \\
\beta=0.20^{* * *} \\
\beta=0.13^{* * *} \\
\beta=0.08^{* *} \\
\beta=0.20^{* * *} \\
{[\text { Structural equation modeling] }}\end{array}$ \\
\hline 6 & $\begin{array}{l}\text { Peter \& } \\
\text { Valkenburg } \\
(2009 b)\end{array}$ & $\begin{array}{l}\mathrm{N}=1052 \\
\text { Age: } 13-20 \\
\text { (Mean }=16.8) \\
\text { Male: } 49 \%\end{array}$ & Yes & $\begin{array}{l}\text { Sexual } \\
\text { satisfaction }\end{array}$ & & $\begin{array}{l}\text { Gender } \\
\text { Sexual } \\
\text { experience } \\
\text { Perceived } \\
\text { sexual } \\
\text { experience of } \\
\text { peers }\end{array}$ & $\begin{array}{l}\text { - SEM use predicted sexual satisfaction and vice versa } \\
\text { - Increased sexual experience decreased the negative } \\
\text { effect of SEM on sexual satisfaction } \\
\text { - Having more sexually experienced peers decreased the } \\
\text { negative effect of SEM on sexual satisfaction }\end{array}$ & $\begin{array}{l}\beta=-0.10^{* * *} ; \beta=-0.08^{* * *} \\
{[\text { Structural equation modeling }]}\end{array}$ \\
\hline 6 & $\begin{array}{l}\text { Peter \& } \\
\text { Valkenburg } \\
\text { (2010a) }\end{array}$ & $\begin{array}{l}\mathrm{N}=956 \\
\text { Age: } 13-20 \\
\text { (Mean }=16.8) \\
\text { Male: } 49 \%\end{array}$ & Yes & $\begin{array}{l}\text { Sexual } \\
\text { uncertainty }\end{array}$ & $\begin{array}{l}\text { Involvement } \\
\text { in SEM }\end{array}$ & Gender & $\begin{array}{l}\text { - SEM use predicted sexual uncertainty } \\
\text { - SEM use predicted involvement in SEM } \\
\text { - Involvement in SEM predicted sexual uncertainty }\end{array}$ & $\begin{array}{l}\beta=0.06^{*} \\
\beta=0.20^{* * *} ; \beta=0.26^{* * *}(\mathrm{~F}) \\
\beta=0.09^{* *} \\
{[\text { Structural equation modeling] }}\end{array}$ \\
\hline
\end{tabular}




\section{Table 2 (continued)}

\begin{tabular}{|c|c|c|c|c|c|c|c|c|}
\hline $\begin{array}{l}\text { Research } \\
\text { project } \\
\text { ID } \\
\end{array}$ & $\begin{array}{c}\text { Authors } \\
\text { (publication year) }\end{array}$ & $\begin{array}{c}\text { Sample } \\
\text { demographics }\end{array}$ & $\begin{array}{c}\text { SEM } \\
\text { definition }\end{array}$ & Outcome & Mediators & Moderators & Key findings & $\begin{array}{l}\text { Effect size } \\
\text { [data analysis] }\end{array}$ \\
\hline 6 & $\begin{array}{l}\text { Peter \& } \\
\text { Valkenburg } \\
\text { (2010b) }\end{array}$ & $\begin{array}{l}\mathrm{N}=959 \\
\text { Age: } 13-20 \text { (Mean } \\
=16.8 \text { ) } \\
\text { Male: } 49 \%\end{array}$ & Yes & $\begin{array}{l}\text { Instrumental } \\
\text { attitudes } \\
\text { toward sex }\end{array}$ & $\begin{array}{l}\text { Perceived } \\
\text { social } \\
\text { realism of } \\
\text { SEM } \\
\text { Perceived } \\
\text { social utility } \\
\text { of SEM }\end{array}$ & Gender & $\begin{array}{l}\text { - SEM use predicted instrumental attitudes towards sex } \\
\text { - SEM use predicted perceived social realism } \\
\text { - Perceived social realism predicted instrumental attitudes } \\
\text { towards sex } \\
\text { - SEM use predicted perceived social utility } \\
\text { - Perceived social utility predicted instrumental attitudes } \\
\text { toward sex }\end{array}$ & $\begin{array}{l}\beta=0.11^{* * *} \\
\beta=0.07 * \\
\beta=0.10^{* *} \\
\beta=0.13^{* * *} \\
\beta=0.13^{* * *} \\
{[\text { Structural equation modeling] }}\end{array}$ \\
\hline 7 & $\begin{array}{l}\text { Peter \& } \\
\text { Valkenburg } \\
\text { (2011) }\end{array}$ & $\begin{array}{l}\mathrm{N}=1445 \\
\text { adolescents and } \\
833 \text { adults } \\
\text { Age: } 12-17 \text { (Mean } \\
=14.5) ; 18+ \\
\text { (Mean }=47.9 \text { ) } \\
\text { Male: } 51 \% \text { of } \\
\text { adolescents and } \\
49 \% \text { of adults }\end{array}$ & Yes & $\begin{array}{l}\text { Stereotypical } \\
\text { beliefs about } \\
\text { women's } \\
\text { sexual roles }\end{array}$ & - & Gender & $\begin{array}{l}\text { - SEM use did not predict stereotypical beliefs about } \\
\text { women's sexual roles among adolescents }\end{array}$ & $\begin{array}{l}\beta=-0.01 \text { (not significant) } \\
\text { [Structural equation modeling] }\end{array}$ \\
\hline 7 & $\begin{array}{l}\text { Peter \& } \\
\text { Valkenburg } \\
\text { (2011a) }\end{array}$ & $\begin{array}{l}\mathrm{N}=1445 \\
\text { adolescents and } \\
833 \text { adults } \\
\text { Age: } 12-17 \text { (Mean } \\
=14.5 \text { ); } 18+ \\
\text { (Mean }=47.9 \text { ) } \\
\text { Male: } 51 \% \text { of } \\
\text { adolescents and } \\
49 \% \text { of adults }\end{array}$ & Yes & $\begin{array}{l}\text { Sexual risk } \\
\text { behavior }\end{array}$ & - & $\begin{array}{l}\text { Gender } \\
\text { Age }\end{array}$ & $\begin{array}{l}\text { - SEM use did not predict sexual risk behavior among } \\
\text { adolescents }\end{array}$ & $\begin{array}{l}\text { OR }=0.98 \text { (not significant) } \\
\text { [Logistic regression] }\end{array}$ \\
\hline
\end{tabular}




\section{Table 2 (continued)}

\begin{tabular}{|c|c|c|c|c|c|c|c|c|}
\hline $\begin{array}{l}\text { Research } \\
\text { project } \\
\text { ID }\end{array}$ & $\begin{array}{c}\text { Authors } \\
\text { (publication year) }\end{array}$ & $\begin{array}{c}\text { Sample } \\
\text { demographics }\end{array}$ & $\begin{array}{c}\text { SEM } \\
\text { definition }\end{array}$ & Outcome & Mediators & Moderators & Key findings & $\begin{array}{c}\text { Effect size } \\
\text { [Data analysis] }\end{array}$ \\
\hline 7 & $\begin{array}{l}\text { Peter \& } \\
\text { Valkenburg } \\
\text { (2011b) }\end{array}$ & $\begin{array}{l}\mathrm{N}=1445 \\
\text { adolescents and } \\
833 \text { adults } \\
\text { Age: } 12-17 \text { (Mean } \\
=14.5) ; 18+ \\
\text { (Mean }=47.9 \text { ) } \\
\text { Male: } 51 \% \text { of } \\
\text { adolescents and } \\
49 \% \text { of adults }\end{array}$ & Yes & SEM use & - & - & $\begin{array}{l}\text { Increased SEM use was predicted by: } \\
\text { - Gender } \\
\text { - Higher sensation seeking } \\
\text { - Lower life satisfaction } \\
\text { - Not being exclusively heterosexual }\end{array}$ & $\begin{array}{l}\beta=-0.26 * * *(\mathrm{M}) \\
\beta=0.05^{* *} \\
\beta=-0.04 * \\
\beta=-0.22 * * * \\
\text { [Multiple regression] }\end{array}$ \\
\hline 8 & $\begin{array}{l}\text { Vandenbosch \& } \\
\text { Eggermont } \\
(2013)\end{array}$ & $\begin{array}{l}\mathrm{N}=639 \\
\text { Age: } 12-16 \text { (Mean } \\
=14.8) \\
\text { Male: } 58 \%\end{array}$ & Yes & $\begin{array}{l}\text { Sexual } \\
\text { initiation }\end{array}$ & - & $\begin{array}{l}\text { Pubertal } \\
\text { stage }\end{array}$ & $\begin{array}{l}\text { - SEM using adolescents in advanced pubertal stage were } \\
\text { less likely to initiate sexual intercourse than SEM using } \\
\text { adolescents in early pubertal stage }\end{array}$ & $\begin{array}{l}\text { OR }=0.4 \text { ( } 95 \% \text { CI: } 0.01,0.48) \\
\text { [Logistic regression] }\end{array}$ \\
\hline 5 & $\begin{array}{l}\text { Vandenbosch } \\
(2015)\end{array}$ & $\begin{array}{l}\mathrm{N}=1765 \text { (data } \\
\text { from } 1 \text {. and } 2 . \\
\text { wave) } \\
\text { Age: } 13-17 \text { (Mean } \\
=15.0) \\
\text { Male: } 50 \%\end{array}$ & Yes & $\begin{array}{l}\text { Content- } \\
\text { specific } \\
\text { types of } \\
\text { SEM }\end{array}$ & - & Gender & $\begin{array}{l}\text { - Age predicted use of affection-themed SEM } \\
\text { - Age predicted use of dominance-themed SEM } \\
\text { - Academic achievement predicted use of dominance- } \\
\text { themed SEM } \\
\text { - Hypergendered orientation predicted use of violence- } \\
\text { themed SEM }\end{array}$ & $\begin{array}{l}\beta=-0.06^{*} \\
\beta=0.08^{* *} \\
\beta=0.06^{*} \\
\beta=0.12^{*} \\
{[\text { Structural equation modeling] }}\end{array}$ \\
\hline 9 & $\begin{array}{l}\text { Ybarra, Mitchell, } \\
\text { Hamburger, } \\
\text { Diener-West, \& } \\
\text { Leaf } \\
(2011)\end{array}$ & $\begin{array}{l}\mathrm{N}=1159 \\
\text { Age: } 10-15 \text { (Mean } \\
=12.6) \\
\text { Male: } 49 \%\end{array}$ & No & $\begin{array}{l}\text { Sexually } \\
\text { aggressive } \\
\text { behavior }\end{array}$ & - & - & $\begin{array}{l}\text { - Intentional exposure to violent SEM predicted sexually } \\
\text { aggressive behavior }\end{array}$ & $\begin{array}{l}\text { OR }=5.8(95 \% \text { CI: } 3.02,10.5) \\
\text { [Logistic regression] }\end{array}$ \\
\hline
\end{tabular}

Note, $\mathrm{nr}=$ not reported; $\beta=$ standardized regression coefficient $; \mathrm{OR}=$ odds ratio; $\mathrm{RR}=$ rate ratio $\mathrm{B}=$ multinomial regression coefficients $; \mathrm{CI}=$ confidence interval; $\mathrm{M}=$ male participants; $\mathrm{F}=$ female participants; $* \mathrm{p}<0.05 ; * * \mathrm{p}<0.01 ; * * * \mathrm{p}<0.001$ 